\title{
Economic Growth and Environmental Sustainability: Empirical Evidence from East and South-East Asia
}

\author{
Md. Samsul ALAM ${ }^{1} \&$ Md. Nurul KABIR ${ }^{2}$ \\ ${ }^{1}$ Graduate School of Asia Pacific Studies, Ritsumeikan Asia Pacific University, Japan \\ ${ }^{2}$ Department of Accounting Finance and Economics, Griffith University, Australia \\ Correspondence: Md. Nurul kabir, Department of Accounting and Finance, Griffith Business School, Australia. \\ Tel: 61-470-635-893. E-mail: mdnurul.kabir@griffithuni.edu.au \\ Received: November 30, 2012 \\ Accepted: January 2, 2013 \\ Online Published: January 11, 2013 \\ doi:10.5539/ijef.v5n2p86 \\ URL: http://dx.doi.org/10.5539/ijef.v5n2p86
}

\begin{abstract}
This study investigates the relationship between economic growth and environmental sustainability in the East and South-East Asian countries focused on the environmental Kuznets curve hypothesis, using data from environmental performance index (EPI) in 2010. Both pollution and eco-efficiency measures, two components of environmental sustainability, are considered as dependent variables while GDP per capita is used as an independent variable. Besides independent variable, the study also considers population density and civil and political liberty index (CIVLIB) as control variables and East and South-East Asia as a dummy variable. By using ordinary least square (OLS) method, this study reveals that while the increase of the GDP per capita appears to have positive impact on the pollution measures, it is found mix (both positive and negative) results on eco-efficiency measures. These findings prove the hypothesis of environmental Kuznets curve partially but not entirely. We conclude the paper by suggesting that the policy makers should give priority to the eco-efficiency measures along with pollution measures in order to ensure environmental sustainability in the process of economic development.
\end{abstract}

Keywords: economic growth, environmental sustainability, kuznets curve

JEL Classification: $\mathrm{O} 1, \mathrm{O} 2, \mathrm{O} 5$

\section{Introduction}

The relationship between economic growth and environmental sustainability has been receiving an intensified attention from the researchers since the early 1970 s as the world policy makers have started to realize the importance of environmental sustainability with the increasing economic growth. Economic growth refers to the persistence increase in economic activity to produce and consume goods and services over a certain period of time in order to improve the quality of life. Although these increasing production and consumption activities are desirable for their positive social and economic impacts, at the same time it is also important to maintain the environmental sustainability as it is now proven that the economic growth and environmental quality are intricately interrelated to each other over time (Orubu and Omotor, 2010). However, it is not that straightforward to regard this inter-connection as either positive or negative, as the existing literature is divided in their opinions by supporting either of the two directions and thus, the issue still remains controversial.

Traditional economic theory suggests a trade-off between economic growth and the quality of the environment. For example, Stagl (1999) and Smulders (2000) argue that the relationship between economic growth and environmental sustainability during 1970-1990 was largely influenced by the material balance paradigm which recommends that the economic growth has a detrimental impact on the environmental sustainability. However, since the early 1990s, an important path-breaking understanding with regard to the relationship between economic growth and environmental sustainability has been derived to challenge the understanding of the traditional economic theory. To illustrate it more, Borghesi and Vercilli (2003), Grossman and Krueger (1993), Hill and Magnani (2002), Pearce and Warford (1993), Selden and Song (1994) and World Bank (1992) are some of the pioneer studies that provide the evidences in favor of the relationship between economic growth and environmental improvement by arguing that both are compatible to each other and economic growth is a perquisite for the environmental sustainability. They find that there is an inverted U-relationship exists between 
the GDP per capita increase and some indicators of environmental quality. Consequently, they coined the term 'Environmental Kuznets Curve' (EKC) for this phenomenon.

The argument to support the EKC is plausibly intuitive. Every economy on its early stage of economic development gives high interest on increasing industrial production which causes rapid pollution. Moreover, the policy makers also emphasize more on the generation of income rather than on the maintenance of environment. However, during the later stage of the development process when income reaches to a sufficiently high level, people become more conscious regarding the clean environment than the income and accordingly, policy makers, government, and regulatory institutions pay more attention to the environment which eventually helps pollution level to decline. Therefore, the EKC curve reveals that the economic growth can be compatible to environmental sustainability.

Substantial literature has been attempted so far to derive at the EKC relationship either by adopting theoretical approaches or empirical evidences. For example, Arrow et al. (1992), Andreoni and Levinson (2000), Grossman and Kruger (1995), John and Pecchenino (1994), Selden and Song (1995), Stokey (1998) and Suri and Chapman (1998), Stern (2003) are few of the most cited studies that contribute greatly to the theoretical development of EKC. In addition to the theoretical aspects, Bhattarai and Hamming (2001), Binder and Neumayer (2005), Cole et al. (1997), Carson et al., (1997), Lists and Gallet (1999), Lee (2005), Liu et el.,(2007), Shafiq and Bandopadhyay (1992), and Song et al., (2008) are the pioneer studies that prove the concept of EKC empirically with regard to both developing and developed countries.

However, it is important to mention that all of the above-mentioned studies focus on the relationship between economic growth and pollution while pollution represents only part of the environmental problem. To be specific, these studies particularly concentrate on air pollution and water pollution. Nevertheless, environment includes other factors as well such as biodiversity, ecosystem, natural resource and energy efficiency, etc., which are also important for maintaining environment sustainability as a whole. The relationship between economic growth and all of the important environmental factors still remains substantially unexplored, as no study prior to this has attempted to tackle this issue. In this regard, focusing on the EKC hypothesis, this study is, therefore, undertaken to explore the relationship between the economic growth and environment as whole by using cross-country data for some selected East and the South-East Asian countries (Note 1). The data regarding environment related variables have been gathered from the 2010 Environmental Performance Index (EPI).

While this paper adopts the same methodology similar to Lee et al., (2005), however this paper is substantially different from their work as this study particularly focuses on East and South-east Asian countries and updated data have been considered for this analysis. Therefore, findings of this paper contribute to the literature in its original form.

Apart from the introduction, the rest of the paper is structured as follows. Section 2 gives the general overview of the EPI and its framework. The general picture of the relationship between the GDP per capita and different indicators of environmental sustainability by using scatter plots is presented in section 3 . Section 4 provides the econometric analysis and empirical findings while section 5 concludes the paper.

\section{The Environmental Performance Index (EPI) and Its Framework}

The EPI is a composite index that produces a wide range of socio-economic, environmental, political and institutional indicators which have tremendous influence on environmental sustainability at the national level. To illustrate it more, the index covers comprehensive information about the core pollution and institutional policies and capabilities to change future pollution and resource use trajectories (Emerson et al., 2010). The index has been published by Yale Center for Environmental Law \& Policy at Yale University in collaboration with Columbia University's Center for International Earth Science Information Network in every two or three year interval since 2005.

The 2010 EPI has been prepared based on the pilot environmental sustainability index in the year 2000 to 2008 and includes all important opinions and feedbacks from more than 70 governments and hundreds of policymakers who are working on environmental issues. The 2010 EPI presents an arbitrary weight of the 25 indicator scores out of ten core policy categories. The ten core policy categories are as follows: environmental burden of disease, water resources for human health, air quality for human health, air quality for ecosystem, water Resources for ecosystems, biodiversity and habitat, forestry, agriculture, carbon-di-oxide and climate Change. All 25 indicators and their weighted scores are presented in the Table1. 
Table 1. EPI Component, Indicators and Indicator Weighted Score

\begin{tabular}{|c|c|c|c|c|}
\hline Index & Objectives & Policy Categories & Indicators & Score \\
\hline \multirow{23}{*}{ EPI } & \multirow{5}{*}{$\begin{array}{l}\text { Environmental } \\
\text { Health/Pollution }\end{array}$} & $\begin{array}{c}\text { Environmental burden of } \\
\text { disease }\end{array}$ & Environmental burden of disease & $25 \%$ \\
\hline & & \multirow{2}{*}{$\begin{array}{l}\text { Air pollution (effects on } \\
\text { human) }\end{array}$} & Indoor air pollution & $6.3 \%$ \\
\hline & & & Outdoor air pollution & $6.3 \%$ \\
\hline & & \multirow{2}{*}{$\begin{array}{l}\text { Water pollution (effects on } \\
\text { human) }\end{array}$} & Access to Water & $6.3 \%$ \\
\hline & & & Access to Sanitation & $6.3 \%$ \\
\hline & \multirow{18}{*}{ Ecosystem } & \multirow{4}{*}{$\begin{array}{l}\text { Air Pollution (effects on } \\
\text { ecosystem) }\end{array}$} & $\begin{array}{l}\text { Sulfur dioxide emissions per } \\
\text { populated land area }\end{array}$ & $2.1 \%$ \\
\hline & & & Nitrogen oxides emissions per populated land area & $0.7 \%$ \\
\hline & & & $\begin{array}{l}\text { Non-methane volatile organic } \\
\text { compound emissions per } \\
\text { populated land area }\end{array}$ & $0.7 \%$ \\
\hline & & & Ecosystem ozone & $0.7 \%$ \\
\hline & & \multirow{3}{*}{ Water (effects on ecosystem) } & Water quality index & $2.1 \%$ \\
\hline & & & Water stress index & $1 \%$ \\
\hline & & & Water scarcity index & $1 \%$ \\
\hline & & \multirow{3}{*}{ Biodiversity \& Habitat } & Biome protection & $2.1 \%$ \\
\hline & & & Marine protection & $1 \%$ \\
\hline & & & Critical habitat protection & $1 \%$ \\
\hline & & \multirow[t]{2}{*}{ Forestry } & Growing stock change & $2.1 \%$ \\
\hline & & & Forest cover change & $2.1 \%$ \\
\hline & & \multirow{3}{*}{ Agriculture } & Agricultural water intensity & $0.8 \%$ \\
\hline & & & Agricultural subsidies & $1.3 \%$ \\
\hline & & & Pesticide regulation & $2.1 \%$ \\
\hline & & \multirow[b]{3}{*}{ Climate Change } & $\begin{array}{l}\text { Greenhouse gas emissions per capita (including land use } \\
\text { emissions) }\end{array}$ & $12.5 \%$ \\
\hline & & & $\mathrm{CO} 2$ emissions per electricity generation & $6.3 \%$ \\
\hline & & & $\begin{array}{l}\text { Industrial greenhouse gas } \\
\text { emissions intensity }\end{array}$ & $6.3 \%$ \\
\hline
\end{tabular}

Source: Yale Center for Environmental Law \& Policy (2010)

The EPI 2010 ranks 163 countries where Iceland secures the first rank with the highest score of 93.5 while Sierra Leone has the lowest score with 32.1. The top five scorers are Iceland, Switzerland, Costa Rica, Sweden, and Norway; while the lowest five are Sierra Leone, Central African Republic, Mauritania, Angola, and Togo. Among the East and South-East Asian countries, Japan and Cambodia secure the highest score of 72.5 and the lowest score of 41.7 , respectively.

Out of these 25 indicators of EPI, this study consider three pollution measures and seven eco-efficiency measure which are directly related with environmental sustainability to examine the relationship between economic growth and environmental sustainability. Three pollution measures are environmental burden of disease (DALY), air quality (Air_H), water quality (Water_H) and 7 indicators for eco-efficiency: water pollution effects on ecosystem (Water_E), emission air pollution effects on ecosystem (Air_E), forestry (FOREST), biodiversity (BIODIV), agriculture (AGRI), carbon-di-oxide (C02KWH_W), and green house gas emission (GHH_CAP) which are major components of environmental sustainability

The remaining 15 indicators are related to social issue, uncontrollable natural disaster, political and governance system and technology and therefore this study excluded these indicators. Hence, the indicators considered in this study are major components of environmental sustainability and the examination of the relationship between economic growth and these two categories of indicators will meet the objective of this study.

\section{The General Picture of Economic Growth and Environmental Sustainability}

In this section, we show the simple scatter plots of original data on the basis of regression output of the selected 
indicators on GDP per capita with regard to the chosen East and South-East Asia's countries. Firstly, the study shows the scatter plots of EPI on per capita GDP in the figure 1( See Appendix). The figure suggests that high per capita GDP holding countries are doing better in environmental performance than the poor per capita GDP holders. However, the low r-squared $(33 \%)$ indicates that many developed countries are still far behind to maintain the expected environmental performance. For instance, although the GDP per capita of South Korea has been progressing rapidly for the last couple of decades, the environmental performance has not been improving along with its GDP growth.

The regression results of environmental pollution or health such as environmental burden of disease (DALY), air quality (Air_H), water quality (Water_H) on GDP per capita are shown in the figure 2-4. All of the three figures demonstrate a positive relationship between the environmental health or pollution and economic growth. These findings suggest that higher econmic growth countries seem to have better environmental health and vice versa.

Figures 5- 11 illustrate the regression outcomes of eco-system related measures of environmental sustainability on GDP per capita. Out of the seven indicators of eco-system, only 2 indicators such as water pollution effects on ecosystem (Water_E) and forestry (FOREST) have a positive relationship with GDP per capita. However, 2 indicators namely air pollution effects on ecosystem (Air_E) and green house gas emission (GHH_CAP) have found to indicate a strong negative relationship with economic growth by maintaining R-squared of 0.204 and 0.538 respectively. The biodiversity (BIODIV), agriculture (AGRI) and carbon-di-oxide (C02kWH_W), the remaining 3 eco-efficiency indicators, seem to have no relationship with GDP per capita increase or decrease.

The general picture of economic growth and environmental sustainability seems very optimistic as high GDP per capita holding countries tend to have better performance in maintaining environmental health and eco-efficiency of environmental sustainability. However, high income countries should give more attention to control air pollution effects on ecosystem and green house gas emission as the results of these indicators are very alarming.

\section{Model of the Income-Environmental Sustainability Relationship}

\subsection{Model and Data}

In order to achieve the objective of this paper, the following econometric specifications have been developed.

$$
\text { Environmental sustainability }=\beta_{0}+\beta_{1} \text { Economic Growth }+\mathbf{s}_{\boldsymbol{t}}
$$

In order to measure the environmental sustainability, which is a dependent variable in this equation, this study considers the EPI score for each country in the year of 2010. The independent variable economic growth is measured by GDP per capita of the year 2010 for each country. GDP per capita is measured as the number of the average population of that country divides the final value of all goods and services produced in a country. GDP per capita is one of the useful indicators to measure the standard of living for a particular country. An increase in GDP would help to make the environment more sustainable, thus expect a positive relationship between GDP per capita and environmental sustainability. Our first hypothesis to be tested in this study is as follows:

\section{$H_{1:}$ There is a positive relationship between GDP per capita and environmental sustainability}

Based on this, new equation takes the following form:

$$
E P I=\beta_{0}+\beta_{1} G D P p c+\varepsilon_{t}
$$

In addition to GDP per capita, this study includes two other control variables, which are land area per capita (PCLAN) and civil and political liberties (CIVLIB). The reason for including PCLAN in the model is that the highly populated country tends to have the high risk for the environmental degradation. Increase in population would lead to deforestation as well as reduce the agricultural land, which have adverse effects on environment. Besides this, population density has also effect on ecological change. Population density is measured by land area per capita for all the countries. Thus this study expects a negative relationship between EPI and population density. Based on this, our second hypothesis is as follows:

\section{$\mathrm{H}_{2}$ : There is a negative relationship between population density (PCLAN) and environmental sustainability}

One of the most important factors that contribute in creating a sustainable environment is civil and political liberty. A country which facilitates the political debate, freedom of voice, fair coordination among the parties, active NGOs would positively contribute to create a sustainable environment, since these activities force the government to think about the enforcement of environmental laws and legislation actively. Civil and political liberties index captures the level of enforcement of legislation and democratic activities for each sample country of this study. A higher score indicates the low level of political liberty. For example, in the year 2012, United States score 1 and treated as full free where the North Korea has score of 7 and considered as a least free country in the world. A number of researchers raise the issue of legislation and freedom of speech, which have an 
influence on the environmental sustainability such as Helliwell (1994), Perrotti (1996) and Barret and Graddy (2000). According to them, countries with a high degree of civil and political liberty tend to take stern action against any pollution/decay to progress the quality of the environment. Based on the above arguments, we develop our third hypothesis as follows:

\section{$H_{3}$ : There is a negative relationship between civil and political liberties index and environmental sustainability}

Finally, this study distinguishes between the East and South-East Asian countries and the countries in the other regions by introducing dummy variables such as 1 is considered for East and South-East Asian countries and 0, if otherwise. The purpose of introducing dummy variables is to explore how the East and South-East Asia's countries perform in contrast with the other regions.

Based on the foregoing discussion, the final model of the equation takes the following form

$$
E P I=B_{0}+B_{1} G D P p c+B_{2} P C L A N+B_{3} C I V L I B+B_{4} \text { East and South-East Asia }+\varepsilon_{\mathrm{t}}
$$

Where:

$$
\begin{aligned}
& \text { EPI = Environmental Performance Index } \\
& \text { GDPpc = GDP per capita under purchasing power parity } \\
& \text { PCLAN = Population Density is the density of people. } \\
& \text { CIVLIB = civil and political liberty index }
\end{aligned}
$$

East and South-East Asia = dummy variable of the East South-East Asia region.

As stated in section two, this research is also interested to examine the relationship between pollution measures and economic growth as well as eco-efficiency measures and economic growth. Consequently, each variable that represent both pollution measure and eco-efficiency have been used as dependent variable in equation (3). All the data for both dependent and independent variable have been collected from environmental performance index report of 2010 and 2008

\subsection{Empirical Results}

This study uses ordinary least square (OLS) method for estimating the results. Before conducting the regression, we have conducted multicollenearity test in order to ensure that the selected variables are not highly correlated with each other. Variance Inflation Factor (VIF) test is used to check multicollineraity among the variables. Under the VIF test, it is suggested that if any variables contains more than 10 VIF value, then the variable is considered to have multicollinearity problem. The VIF test with all the independent variables of our model shows that there is no multicolleniarity problem.

Table 2. Variance Inflation Factor (VIF) test

\begin{tabular}{lll}
\hline Variable & VIF & 1/VIF \\
\hline GDPpc & 2.35 & 0.425961 \\
PCLAN & 1.99 & 0.503721 \\
East ASIA & 1.42 & 0.705948 \\
CIVLAB & 1.16 & 0.862364 \\
\hline
\end{tabular}

After conducting the VIF test, this study first runs the regression on equation (3) where dependent variable is EPI (See Table 3). Moreover, regression results of selected variables of EPI on GDP per capita (GDPpc), population density (PCLAN) and civil and poverty index (CIVLIB) are presented in Table 4, 5 and 6 respectively. 
Table 3. Regression of EPI on GDP per capita, population density, CIVLIB and East and South-East Asia

\begin{tabular}{llll}
\hline Variables & Coefficients & $\mathrm{t}$-Statistic & $\mathrm{P}>[\mathrm{t}]$ \\
\hline GDP per capita & 0.0003282 & 1.97 & 0.045 \\
Population density & -0.000943 & -2.73 & 0.000 \\
CIVLIB & -1.747509 & -1.43 & 0.187 \\
East and South-East Asia & 5.68731 & 0.95 & 0.366 \\
Constant & 56.86888 & 6.02 & 0.000 \\
Prob $>$ F & 0.0183 & & \\
R squared & 0.5040 & & \\
Adj R- squared & 0.2835 & & \\
\hline
\end{tabular}

According to the results based on Table 3, the GDP per capita has a positive relationship with the overall index of environmental performance at 5\% significance level. This finding suggests that the higher the GDP per capita, the better the environmental performance. This finding also supports the theoretical argument of 'Environmental Kuznets Curve'. Moreover, regression result of environmental pollution and eco efficiency variables on GDP per capita is presented at Table 4. According to the Table 4, environmental pollution variables such as environmental burden of disease (DALY), effect of Air on human ( Air_H) and effect of Water on human (Water_h) have a positive relationship with GDP per capita. A positive relation between these variables and GDP per capita indicate that if GDP per capita increases, environmental pollution will get lower and an improvement in reducing both air pollution and water pollution. At the same time, an increase in GDP also increases eco efficiency variable that includes Water effect on air, forestation and agricultural production among the sample country. However, the rest of the four variables of eco efficiency measure such as biodiversity, green-house gas emission, $\mathrm{CO} 2$ emission and air effect on environment have negative relationship with GDP per capita which indicate the an increase in GDP Per capita is lowering the score of these variables. Therefore government should take appropriate measurements on these aspects along with GDP growth.

Table 4. Regression of selected measures of EPI on GDP per capita

\begin{tabular}{lccc}
\hline Variables & Coefficients & t-Statistic & $\mathrm{P}>[\mathrm{t}]$ \\
\hline DALY & 0.0010215 & 4.00 & 0.003 \\
Air_H & 0.0008547 & 2.19 & 0.056 \\
Water_H & 0.0009369 & 2.23 & 0.053 \\
Air_E & -0.0000362 & -0.13 & 0.896 \\
Water_E & 0.0001671 & 0.74 & 0.480 \\
BIODIV & -0.0001368 & -2.01 & 0.106 \\
FOREST & 0.0000837 & 0.35 & 0.738 \\
GHH_CAP & -0.0016448 & -4.68 & 0.001 \\
C02KWH_w & -00000625 & -0.52 & 0.616 \\
AGRI & 0.0001733 & 0.51 & 0.624 \\
\hline
\end{tabular}

When the second control variable, population density is regressed against EPI, it shows a negative relationship as predicted by theory (See Table 5). The higher the population density the lower the environmental performances score. The same relationship exists for all the three variables of pollution measurements (See Table 5). Furthermore, increase in population of a particular country lowers the biodiversity and increases deforestation, which has vital impact on environment. Interestingly, from the result it shows increase in population density has positive effect on agriculture, which means more people are employed in agricultural cultivation. 
Table 5. Regression of selected measures of EPI on population density

\begin{tabular}{llcc}
\hline \multicolumn{1}{c}{ Variables } & \multicolumn{1}{c}{ Coefficients } & t-Statistic & $\mathrm{P}>[\mathrm{t}]$ \\
\hline DALY & -0.0008236 & -0.40 & 0.700 \\
Air_H & -0.0008377 & -0.27 & 0.797 \\
Water_H & -0.0017694 & -0.52 & 0.616 \\
Air_E & 0.00176494 & 2.18 & 0.057 \\
Water_E & 0.0036166 & 1.97 & 0.081 \\
BIODIV & -0.0031778 & -0.67 & 0.570 \\
FOREST & -0.0018743 & -1.97 & 0.097 \\
GHH_CAP & 0.0064298 & 2.25 & 0.051 \\
C02KWH_w & -0.0000978 & -0.03 & 0.976 \\
AGRI & 0.0009218 & 0.33 & 0.747 \\
\hline
\end{tabular}

Finally, CIVLIB is negatively related with environmental performance index (See Table 3), suggesting that the higher the CIVLIB score the lower the environmental performance score. Again, if we decompose the EPI score according the environmental pollution and eco-efficiency variables, it shows that, all three pollution variables as well as all the variables of eco-efficiency except agriculture and air effects on environment have the negative relationship with CIVLIB (See Table 6). This finding gives a serious indication that; all sample countries should emphasize on the active enforcement of environmental laws and legislation as well as citizen should raise their democratic voice for a sustainable environment. Therefore it is necessary to have democratic practice in a country which will ensure both the government and citizen can work together to increase sustainable development.

Table 6. Regression of selected measures of EPI on CIVLIB

\begin{tabular}{lccc}
\hline Variables & Coefficients & t-Statistic & $\mathrm{P}>[\mathrm{t}]$ \\
\hline DALY & -1.420441 & -0.82 & 0.435 \\
Air_H & -5.795269 & -2.19 & 0.056 \\
Water_H & -2.74395 & -0.96 & 0.362 \\
Air_E & 2.642911 & 1.44 & 0.183 \\
Water_E & -1.839511 & -1.19 & 0.264 \\
BIODIV & -1.513267 & -0.38 & 0.713 \\
FOREST & -3.02672 & -1.83 & 0.10 \\
GHH_CAP & -2.875849 & -1.20 & 0.260 \\
C02KWH_w & -0.66775 & -0.11 & 0.912 \\
AGRI & 0.1231156 & 0.05 & 0.959 \\
\hline
\end{tabular}

\section{Concluding Remarks}

This study is undertaken to investigate the relationship between economic growth and environmental performance empirically in the context of East and South-East Asian countries. By employing both general analysis and empirical model, it is found that the increase of the GDP per capita appears to have positive impact on the pollution measures. However, the situation is partially true in case of eco-efficiency measures as 3 out of 7 eco-efficiency measures such as water effects on ecosystem, forestry and agriculture are positively affected by the increasing of GDP per capita. Hence, these findings prove the theoretical aspect of the Environmental Kuznets Curve to some extent but not in full extent. The important argument regarding the positive relationship between economic growth and environmental sustainability could be the blessings of economic freedom. It is obvious that when the people become richer, the consciousness and education regarding environment are generally increased. Moreover, the rich people can afford the environment friendly goods and technology more than that of the poor people.

The findings of this study suggest an important dictation to the policy makers of the developing countries in the sense that the policies should not be developed only on the basis of pollution controls; rather it is also necessary to consider the eco-efficiency aspects of environmental sustainability with a view to accelerating the process of economic development. 


\section{References}

Andreoni, J., \& Levinson, A. (2001). The simple analytics of the environmental Kuznets curve. Journal of Public Economics, 80(2), 269-286.

Barrett, S., \& Graddy, K. (2000). Freedom, growth, and the environment. Environment and Development Economics, 5(4), 433-456. http://dx.doi.org/10.1016/S0047-2727(00)00110-9

Bengochea-Morancho, A., Higón-Tamarit, F., \& Martínez-Zarzoso, I. (2001). Economic growth and CO2 emissions in the European Union. Environmental and Resource Economics, 19(2), 165-172. http://dx.doi.org/10.1023/A:1011188401445

Bhattarai, M., \& Hammig, M. (2001). Institutions and the environmental Kuznets curve for deforestation: a crosscountry analysis for Latin America, Africa and Asia. World development, 29(6), 995-1010. http://dx.doi.org/10.1016/S0305-750X(01)00019-5

Binder, S., \& Neumayer, E. (2005). Environmental pressure group strength and air pollution: An empirical analysis. Ecological Economics, 55(4), 527-538. http://dx.doi.org/10.1016/j.ecolecon.2004.12.009

Borghesi, S., \& Vercelli, A. (2003). Sustainable globalisation. Ecological Economics, 44(1), 77-89. http://dx.doi.org/10.1016/S0921-8009(02)00222-7

Carson, R. T., Jeon, Y., \& McCubbin, D. R. (1997). The relationship between air pollution emissions and income: US data. Environment and Development Economics, 2(4), 433-450. http://dx.doi.org/10.1017/S1355770X97000235

Cole, M. A., Rayner, A. J., \& Bates, J. M. (1997). The environmental Kuznets curve: an empirical analysis. Environment and Development Economics, 2(04), 401-416. http://dx.doi.org/10.1017/S1355770X97000211

Emerson, J., Esty, D. C., Levy, M. A., Kim, C.H., Mara, V., Sherbinin, A. D., \& Srebotnjak, T. (2010). 2010 Environmental Performance Index. New Haven: Yale Center for Environmental Law and Policy

Grossman, G. M., \& Krueger, A. B. (1991). Environmental impacts of a North American free trade agreement: National Bureau of Economic Research.

Grossman, G. M., \& Krueger, A. B. (1994). Economic growth and the environment: National Bureau of Economic Research.

Helliwell, J. F. (1994). Empirical linkages between democracy and economic growth. British journal of political science, 24(2), 225-248. http://dx.doi.org/10.1017/S0007123400009790

Hill, R. J., \& Magnani, E. (2002). An exploration of the conceptual and empirical basis of the environmental Kuznets curve. Australian Economic Papers, 41(2), 239-254. http://dx.doi.org/10.1111/1467-8454.00162

John, A., \& Pecchenino, R. (1994). An overlapping generations model of growth and the environment. The Economic Journal, 1393-1410.

Kuznets, S. (1955). Economic growth and income inequality. The American Economic Review, 45(1), 1-28.

Lee, C. C. (2005). Energy consumption and GDP in developing countries: a cointegrated panel analysis. Energy Economics, 27(3), 415-427. http://dx.doi.org/10.1016/j.eneco.2005.03.003

Lee, H., Chung, R. K., \& Koo, C. M. (2005). On the Relationship between Economic Growth and Environmental Sustainability. Paper presented to the Eminent Environmental Economists Symposium, Seoul, Korea

List, J. A., \& Gallet, C. A. (1999). The environmental Kuznets curve: does one size fit all? Ecological Economics, 31(3), 409-423. http://dx.doi.org/10.1016/S0921-8009(99)00064-6

Liu, X., Heilig, G. K., Chen, J., \& Heino, M. (2007). Interactions between economic growth and environmental quality in Shenzhen, China's first special economic zone. Ecological Economics, 62(3), 559-570. http://dx.doi.org/10.1016/j.ecolecon.2006.07.020,

Orubu, C. O., \& Omotor, D. G. (2011). Environmental quality and economic growth: Searching for environmental Kuznets curves for air and water pollutants in Africa. Energy Policy, 39(7), 4178-4188. http://dx.doi.org/10.1016/j.enpol.2011.04.025

Perotti, R. (1996). Growth, income distribution, and democracy: What the data say. Journal of Economic growth, 1(2), 149-187.http://dx.doi.org/10.1007/BF00138861

Selden, T. M., \& Song, D. (1994). Environmental quality and development: is there a Kuznets curve for air pollution emissions? Journal of Environmental Economics and management, 27(2), 147-162. 
http://dx.doi.org/10.1006/jeem.1994.1031

Shafik, N., \& Bandyopadhyay, S. (1992). Economic growth and environmental quality: time-series and cross-country evidence (Vol. 904): World Bank Publications.

Smulders, S. (2000). Economic growth and environmental quality. Principles of environmental and resource economics, Edward Elgar, Cheltenham, 602-664.

Song, T., Zheng, T., \& Tong, L. (2008). An empirical test of the environmental Kuznets curve in China: A panel cointegration approach. China Economic Review, 19(3), 381-392. http://dx.doi.org/10.1016/j.chieco.2007.10.001

Stagl, S. (1999). Delinking economic growth from environmental degradation? A literature survey on the environmental Kuznets curve hypothesis.

Stern, D. I. (2004). The rise and fall of the environmental Kuznets curve. World development, 32(8), 1419-1439. http://dx.doi.org/10.1016/j.worlddev.2004.03.004

Stokey, N. L. (1998). Are there limits to growth? International Economic Review, 1-31.

Suri, V., \& Chapman, D. (1998). Economic growth, trade and energy: implications for the environmental Kuznets curve. Ecological Economics, $195-208$. http://dx.doi.org/10.1016/S0921-8009(97)00180-8

\section{Notes}

Note 1. The countries which are considered in this study are Japan, South Korea, North Korea, Mongolia, Singapore, Malaysia, China, Thailand, Brunei, Laos, Myanmar, Cambodia, Vietnam, Philippine and Indonesia.

\section{Appendix A}

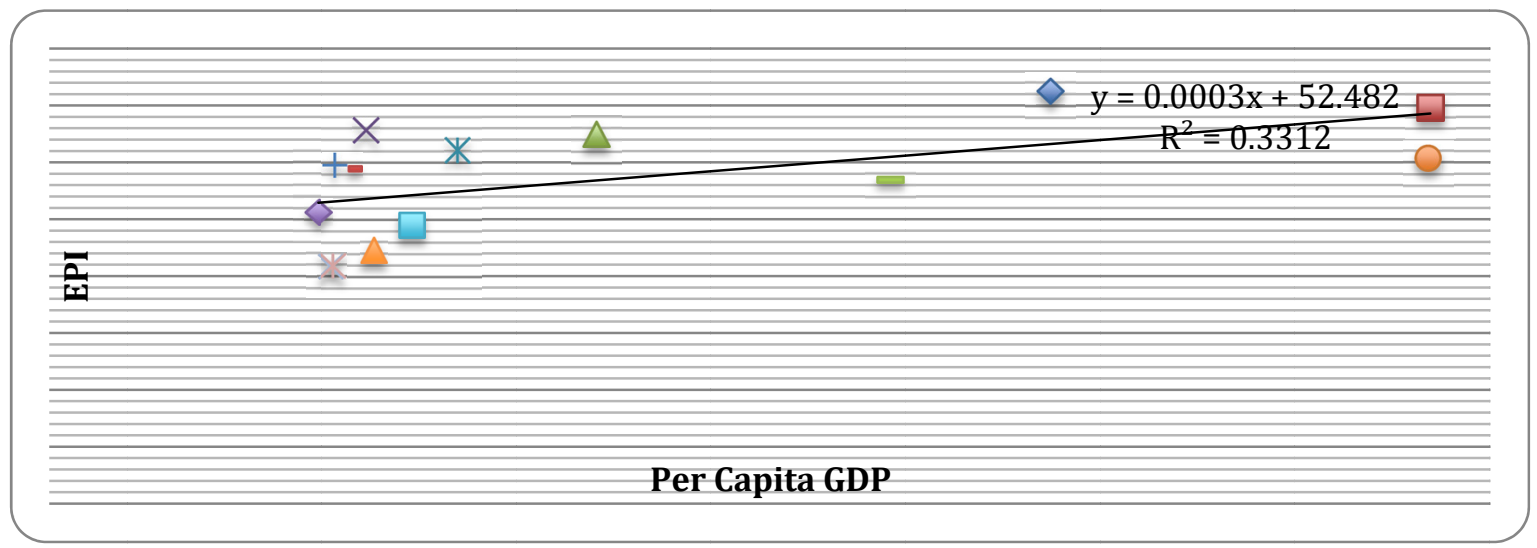

Figure 1. Regression of the EPI on per capita GDP $($ R- squared $=0.331)$

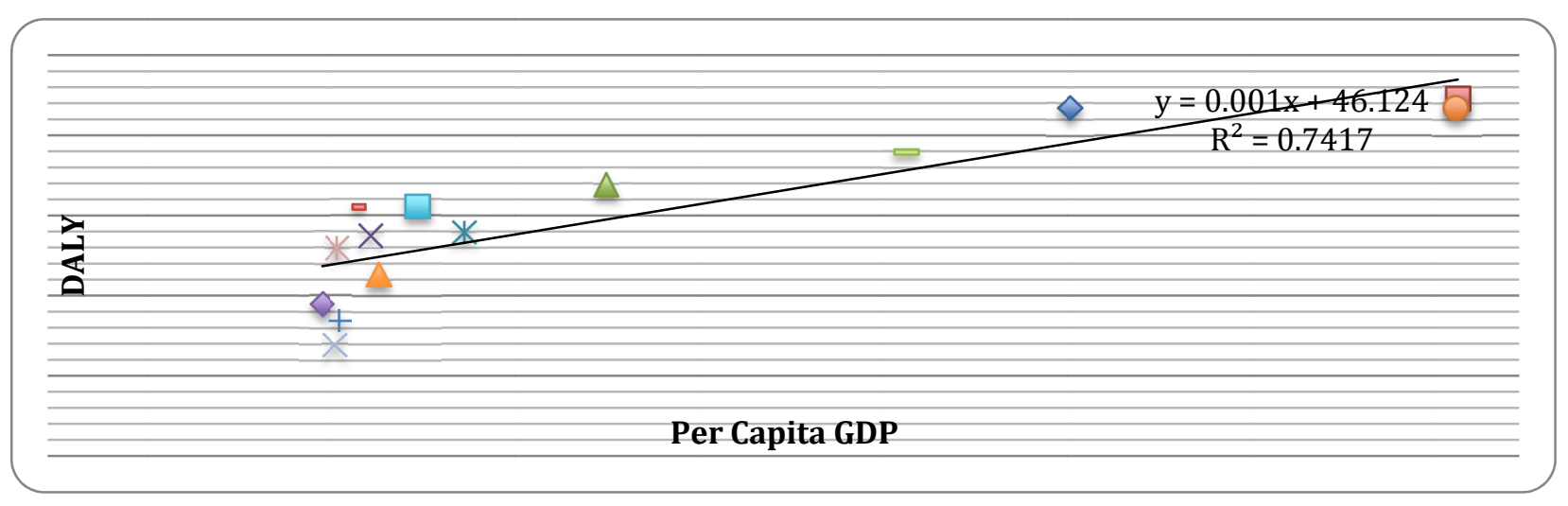

Figure 2. Regression of the environmental burden of disease (DALY) on per capita GDP $($ R- squared $=0.741)$ 


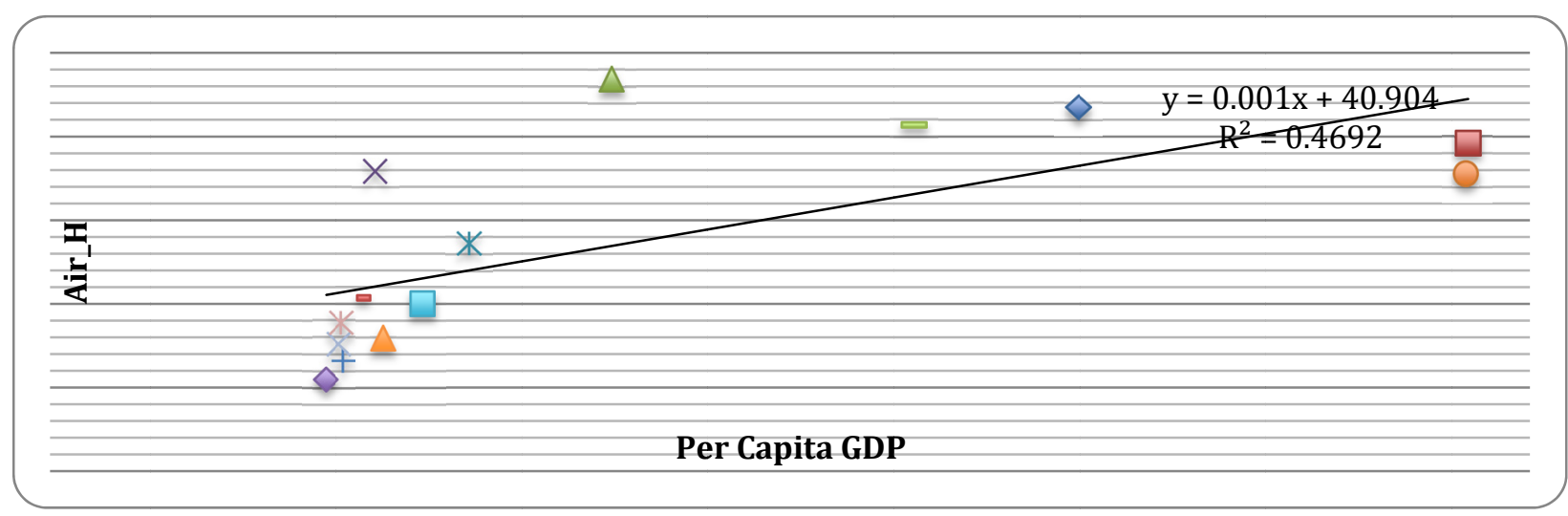

Figure 3. Regression of the air quality (Air_H) on per capita GDP (R- squared $=0.463$ )

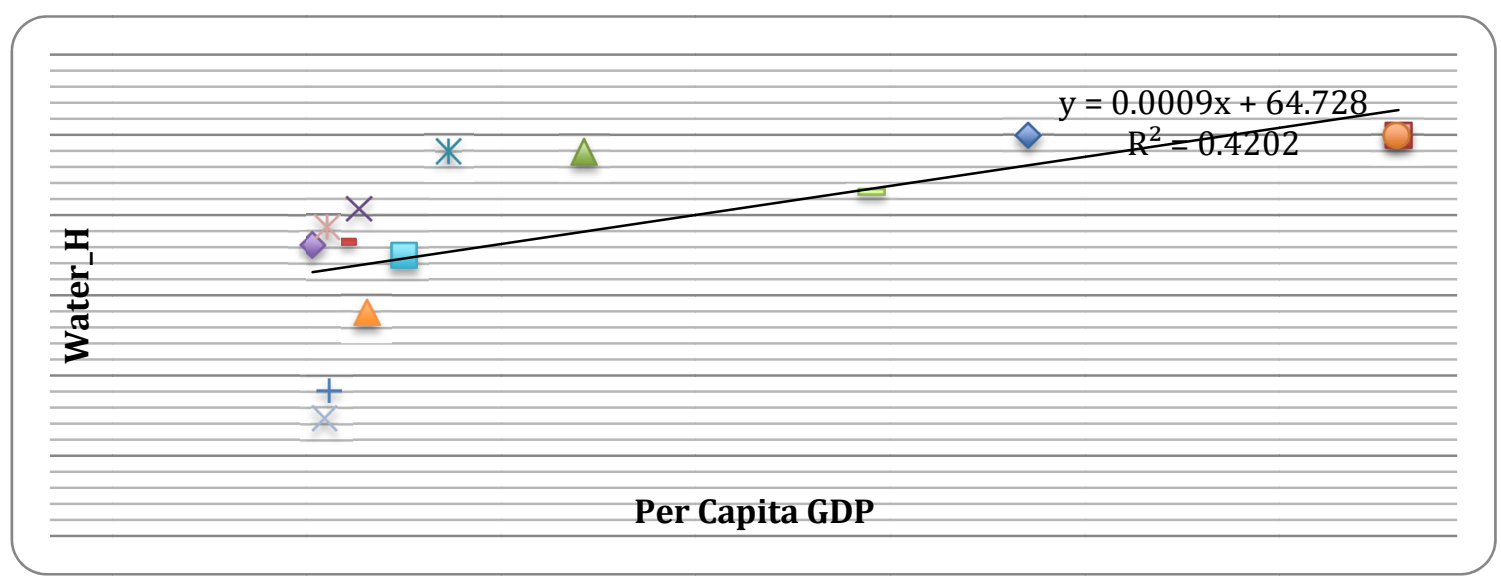

Figure 4. Regression of the water quality (Water_H) on per capita GDP (R- squared $=0.420$ )

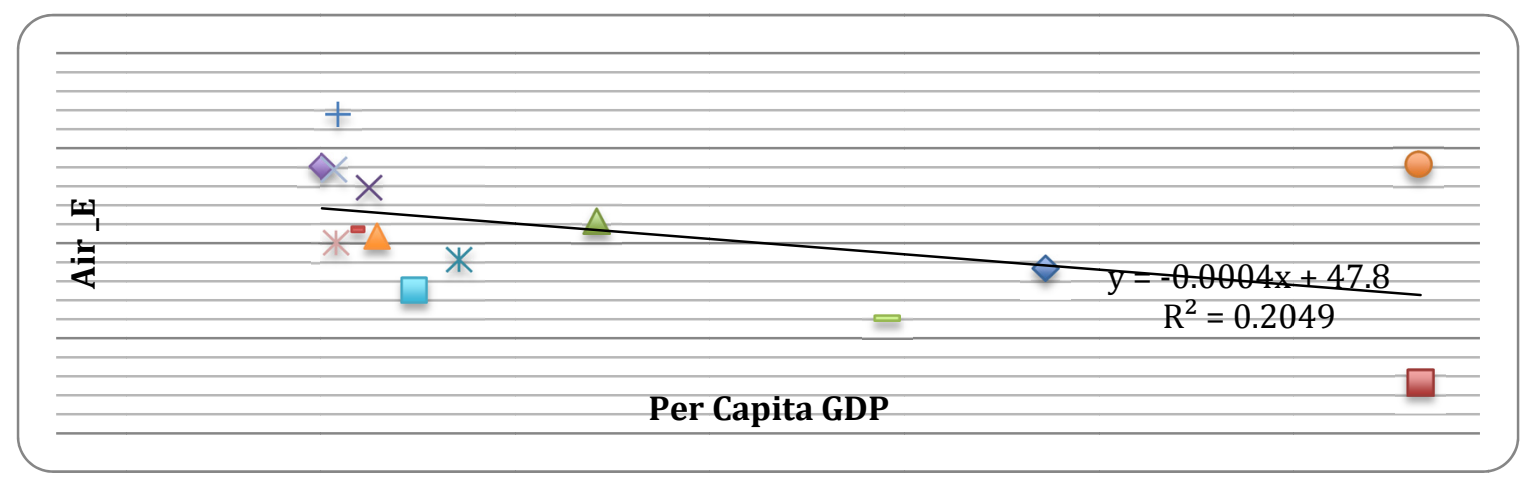

Figure 5. Regression of the Air pollution effects on ecosystem (Air_E) on per capita GDP (R- squared $=0.204$ ) 


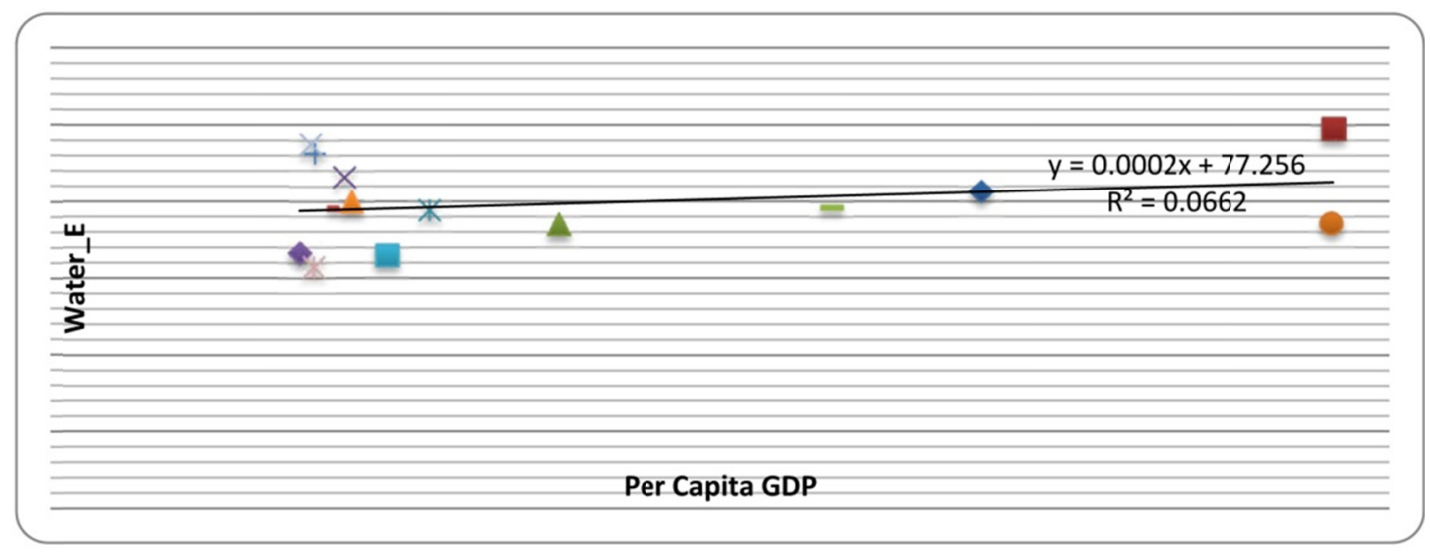

Figure 6. Regression of the water pollution effects on ecosystem (Water_E) on per capita GDP (R- squared $=0.066)$

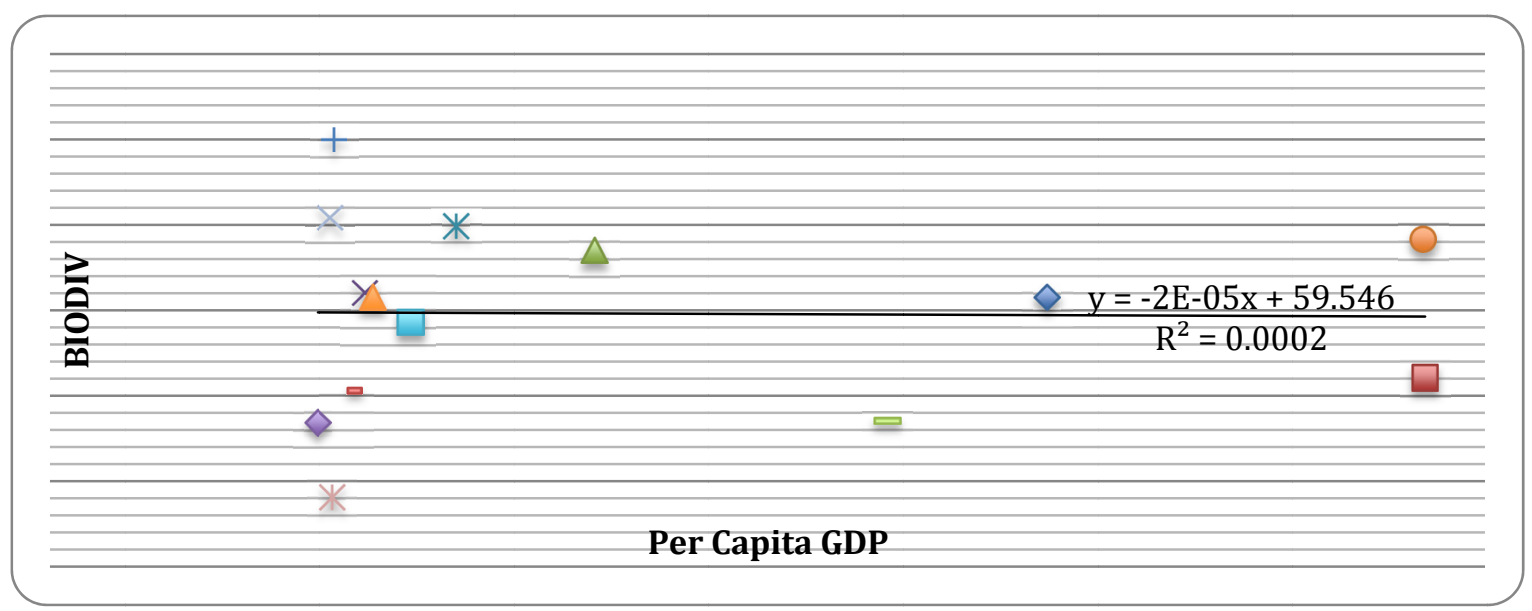

Figure 7. Regression of the biodiversity (BIODIV) on per capita GDP (R- squared $=0.000$ )

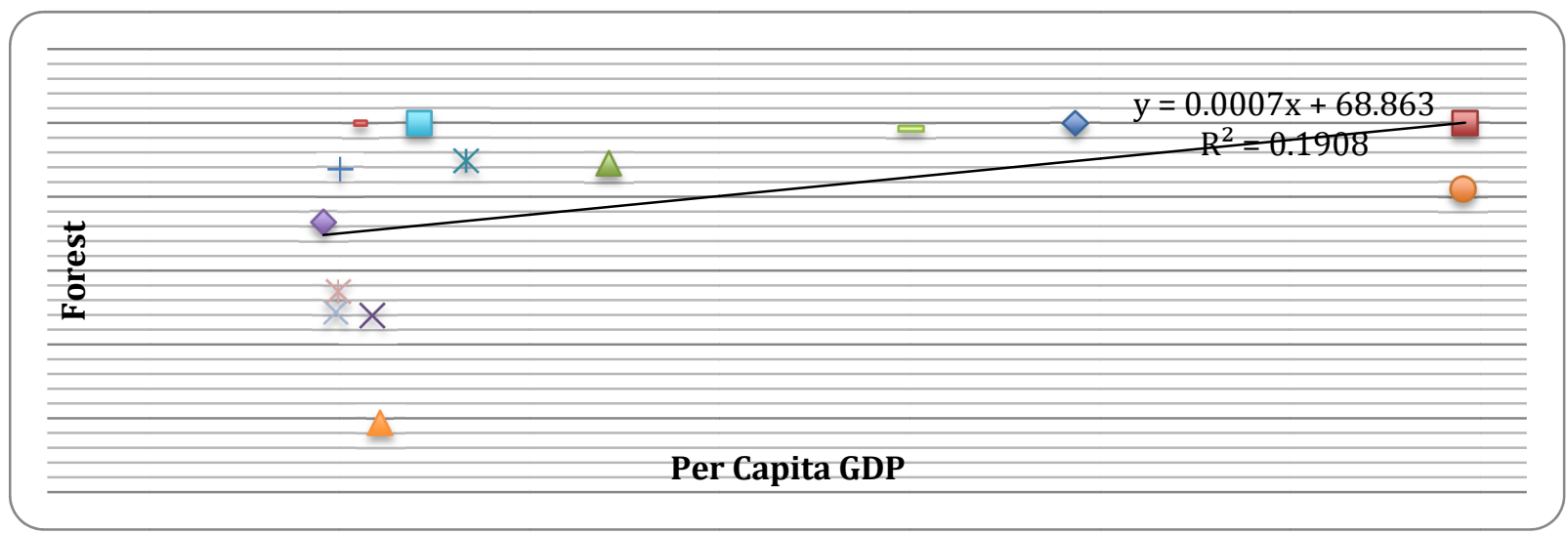

Figure 8. Regression of the forestry (Forest) on per capita GDP (R- squared $=0.192$ ) 


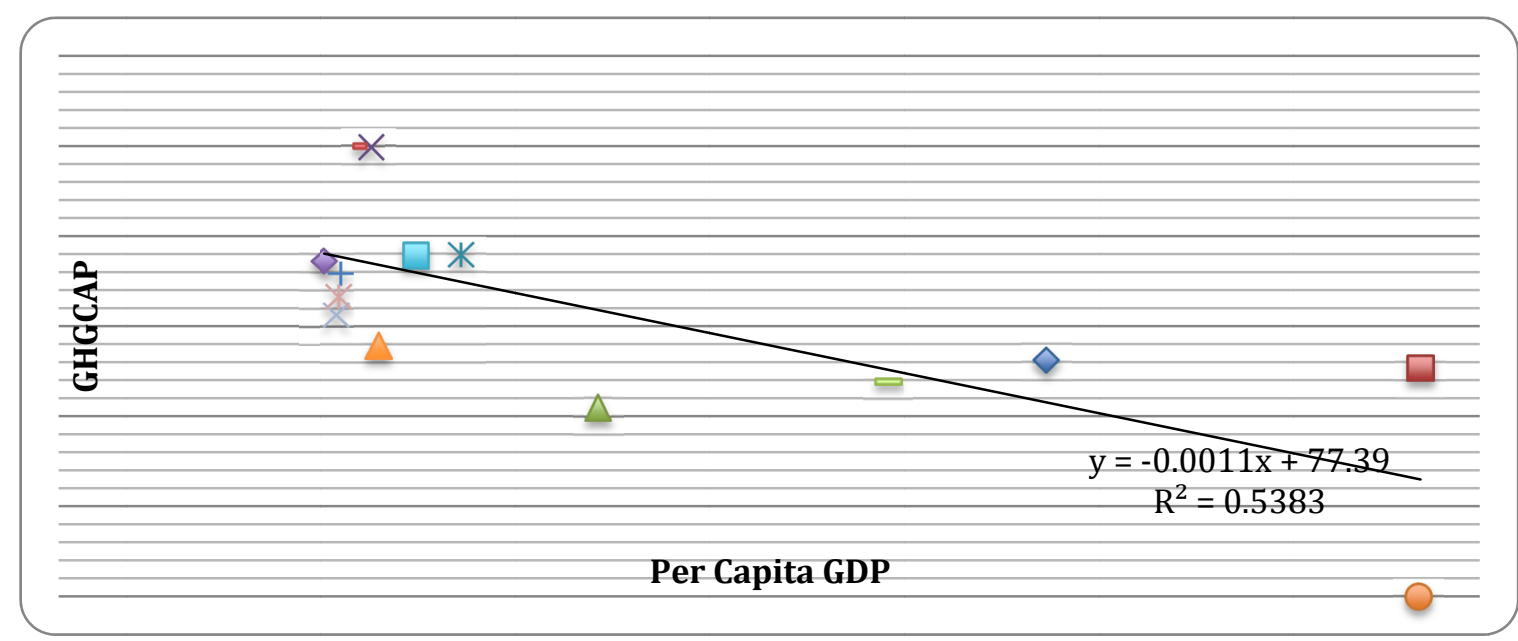

Figure 9. Regression of green house gas emission (GHG-CAP) on per capita GDP (R- squared $=0.538$ )

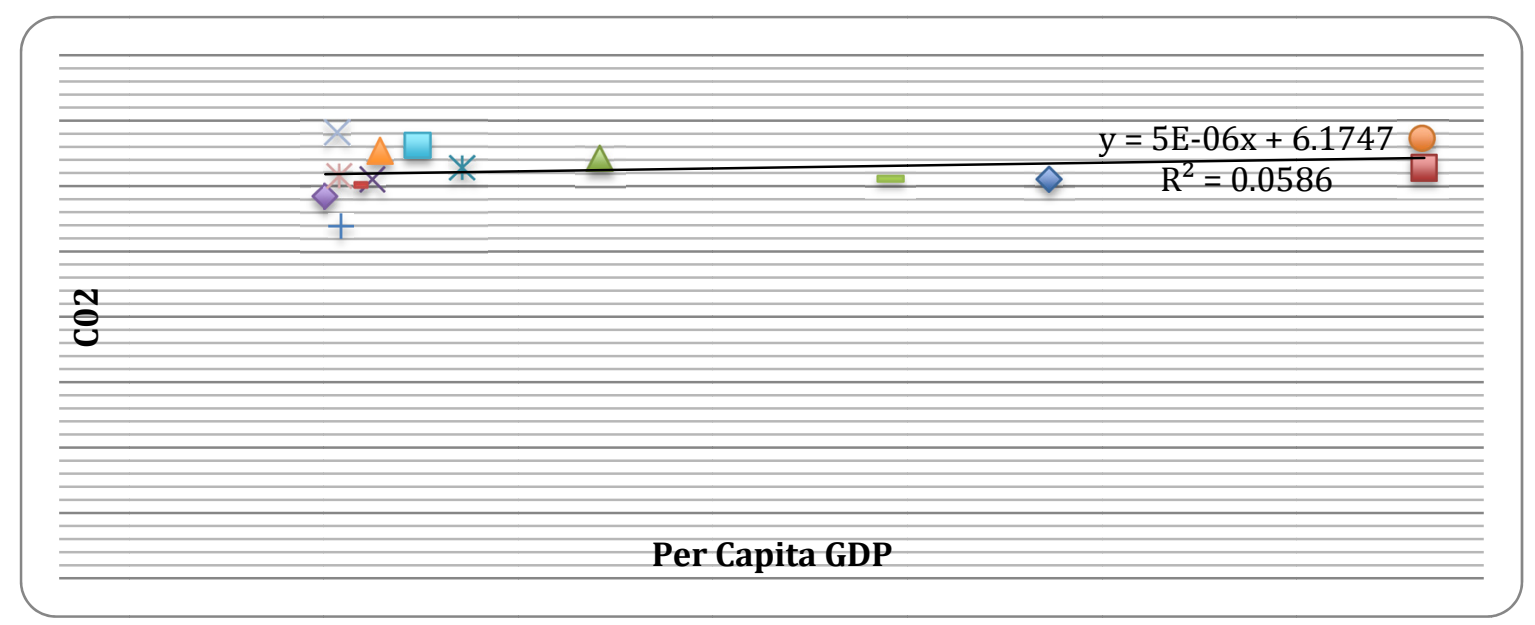

Figure 10. Regression of carbon-di-oxide $(\mathrm{C} 02 \mathrm{kWH}+\mathrm{W})$ emission on per capita GDP (R- squared $=0.058)$

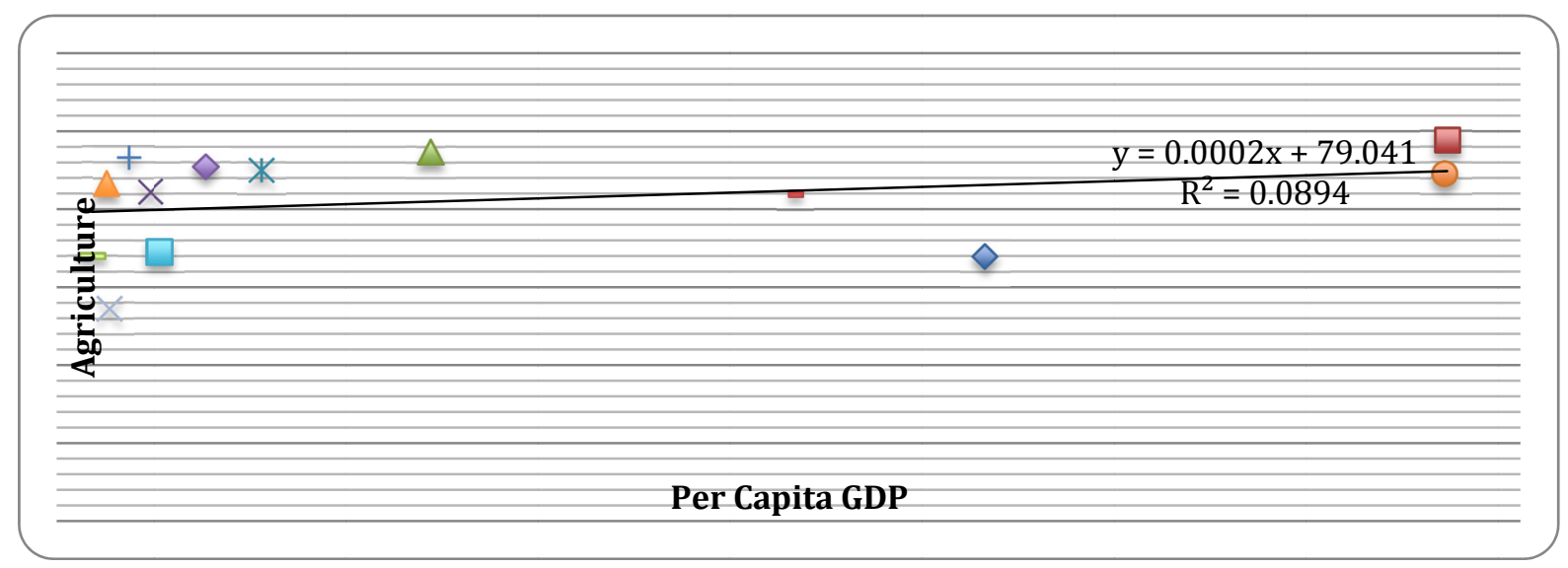

Figure 11. Regression of Agriculture (AGRI) on per capita GDP (R- squared $=0.089)$ 